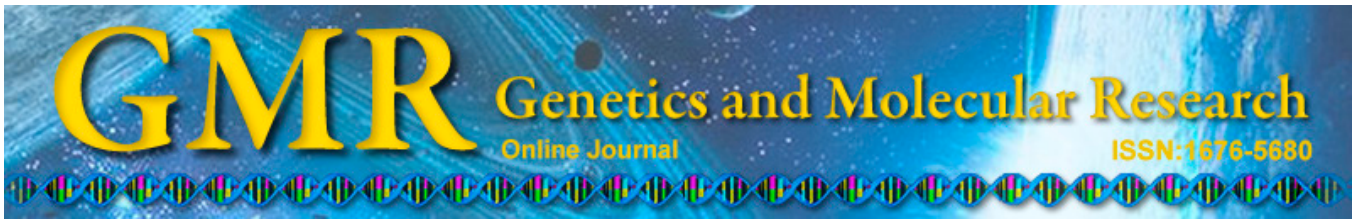

$\underline{\text { Short Communication }}$

\title{
Screening the first set of polymorphic microsatellite loci in Lunella coronata granulata (Turbinidae)
}

\author{
Z.B. Li ${ }^{1,2}$, Q.H. Li ${ }^{1,2}$, J.B. Shangguan ${ }^{1,2}$, Y.F. Ning ${ }^{1,2}$ and G. Dai ${ }^{1,2}$ \\ ${ }^{1}$ Fisheries College, Jimei University, Xiamen, China \\ ${ }^{2}$ Fujian Provincial Key Laboratory of Marine Fishery Resources and \\ Eco-Environment, Xiamen, China \\ Corresponding author: Z.B. Li \\ E-mail: lizhongbao@jmu.edu.cn
}

Genet. Mol. Res. 14 (2): 6319-6322 (2015)

Received July 28, 2014

Accepted January 23, 2015

Published June 11, 2015

DOI http://dx.doi.org/10.4238/2015.June.11.6

\begin{abstract}
Lunella coronata granulata, from the family Turbinidae, is an economically important species. The first set of 10 polymorphic microsatellite loci was screened from $L$. coronata granulata, and 30 individuals were used to analyze the degree of polymorphism in these loci. The level of observed and expected heterozygosity was 0.0667-0.7333 and 0.0644-0.6628, respectively. The polymorphism information content varied from 0.305 to 0.559 . Eight loci were in Hardy-Weinberg equilibrium (HWE) $(\mathrm{P}>0.05)$, while two loci deviated significantly from the HWE after Bonferroni's correction $(\mathrm{P}<$ 0.005). The isolated microsatellite loci can be utilized in studies of population genetic analysis and they provide important genetic markers for construction of genetic linkage maps and genetic breeding of L. coronata granulata resources.
\end{abstract}

Key words: Genetic markers; Lunella coronata granulata; Microsatellite; Magnetic bead enrichment 


\section{INTRODUCTION}

Lunella coronata granulata, from the family Turbinidae, is an edible turbine shell. The snail is widely distributed in temperate and subtropical ocean waters. In China, L. coronata granulata lives in the intertidal rocky zone mostly in Fujian, Guangdong, and Zhejiang provinces. The studies on L. coronata granulata are very limited; only one research has been reported on a digestive enzyme isolated from this species (Chen, 1990). To increase the knowledge of this species, we use microsatellites to investigate genetic characteristics of $L$. coronata granulata. Microsatellites have been widely used in aquatic animals such as fishes (Xu et al., 2010; Chen et al., 2012a), shrimps (Cao et al., 2012), and shellfish (Chen et al., 2012b) for their co-dominance, high DNA polymorphism, and reliability $(\mathrm{Li}, 2006)$. Ten polymorphic microsatellite loci were developed using the fast isolation by amplified fragment length polymorphism of sequences containing repeats method (Zane et al., 2002), which provides a theoretical basis for future marker-assisted population genetic studies and breeding of this species.

\section{MATERIAL AND METHODS}

Thirty individuals of L. coronata granulata were collected from Xiamen Province, China. Total genomic DNA was extracted from the foot muscle tissue using a genomic DNA extraction kit DP304-03 (TIANGEN Biotech Co., Ltd., Beijing, China). After testing the concentration and purity on $1 \%$ agarose gel, the genomic DNA was digested with restriction enzyme $M s e \mathrm{I}$ at $65^{\circ} \mathrm{C}$ for $3.5 \mathrm{~h}$ and the digested fragments were then ligated to $M s e I$ adapter A (5'-ACGATGAGTCCTGAG-3')/MseI adapter B (5'-TACTCAGGACTCAT-3') by T4 DNA ligase at $37^{\circ} \mathrm{C}$ for $3.5 \mathrm{~h}$. Afterwards, two biotinylated probes $(\mathrm{CT})_{15}$ and $(\mathrm{GT})_{15}$ were used to construct genomic libraries as reported in Chen et al. (2012a). In brief, the digestion-ligation mixture was hybridized to the two biotinylated probes, $(\mathrm{GT})_{15}$ and $(\mathrm{CT})_{15}$. Fragments containing simple sequence repeats were captured by the method of magnetic bead enrichment with a Streptavidin MagneSphere Paramagnetic Particles (Promega, Madison, WI, USA). The recovered single DNA fragments were amplified by MseI A primer, ligated to a vector PMD19-T (TaKaRa, Tokyo, Japan) at $16^{\circ} \mathrm{C}$ for $3 \mathrm{~h}$, and subsequently transformed into Escherichia coli. Positive clones were visualized on 1\% agarose gel after PCR amplification with universal M13 primer. A total of 310 positive clones with size ranging from 500 to $1200 \mathrm{bp}$ were sequenced by the Invitrogen Company (Guangzhou, China), and 60 pairs of primers were designed by Primer Premier 5.0 (Premier Biosoft, Palo Alto, CA, USA).

Thirty L. coronata granulata individuals were used to test the polymorphism of all 46 pairs of primers. PCR amplifications were carried out in $10 \mu \mathrm{L}$ volumes containing 10X Taq buffer, $2 \mathrm{mM} \mathrm{MgCl}, 0.2 \mathrm{mM}$ of each dNTP, $0.4 \mu \mathrm{M}$ of each forward and reverse primer, 0.25 U Taq DNA polymerase (Fermentas, Fisher Scientific, Pittsburg, PA, USA), and 50 ng genomic DNA. Cycling parameters consisted of the initial denaturation at $94^{\circ} \mathrm{C}$ for $5 \mathrm{~min}$, followed by 30 cycles of denaturation at $94^{\circ} \mathrm{C}$ for $45 \mathrm{~s}$, annealing at temperature respective to the primers (Table 1) for $45 \mathrm{~s}$, and elongation at $72^{\circ} \mathrm{C}$ for $45 \mathrm{~s}$, with an additional cycle at $72^{\circ} \mathrm{C}$ for 10 min. Samples were separated on $6 \%$ denaturing polyacrylamide gel and visualized using silver staining. Estimates of the number of alleles, observed $\left(H_{\mathrm{O}}\right)$ and expected $\left(H_{\mathrm{E}}\right)$ heterozygosity, Hardy-Weinberg equilibrium (HWE), and genotypic linkage disequilibrium were conducted by POPGEN32 (version1.32) (Yeh et al., 2000). The polymorphism information was indicated by CERVUS 3.0 (Kalinowski et al., 2007). Genotyping errors and null alleles were identified 
and corrected by the Micro-Checker software (Van Oosterhout et al., 2004).

\section{RESULTS AND DISCUSSION}

Ten loci were successfully amplified. The characterizations of these loci are presented in Table 1. Loci were polymorphic, with the polymorphism information content ranging from 0.305 to 0.559 , and the $H_{\mathrm{O}}$ and $H_{\mathrm{E}}$ were from 0.0667 to 0.7333 and 0.0644 to 0.6628 , respectively. No significant linkage disequilibrium was detected between any pair of loci. Of the 10 loci tested, eight loci were in HWE ( $>$ > 0.05), while two loci, Lc2-32 and Lc4-22, deviated significantly from HWE after sequential Bonferroni's correction $(\mathrm{P}<0.005)$, which may be due to the presence of null alleles that were detected by Micro-Checker. These characteristics of the microsatellite loci identified in the present study indicate their potential utility for examining genetic diversity and population genetic structure and they will facilitate breeding and conservation genetic studies of $L$. coronata granulata.

Table 1. Basic genetic information of 10 polymorphism microsatellite loci in Lunella coronata granulata.

\begin{tabular}{|c|c|c|c|c|c|c|c|}
\hline Locus ID & Primer sequence $\left(5^{\prime}-3^{\prime}\right)$ & Allele size (bp) & Repeat motif & $\mathrm{Ta}\left({ }^{\circ} \mathrm{C}\right)$ & PIC & $H_{\mathrm{o}}$ & $H_{\mathrm{E}}$ \\
\hline Lc 45 & $\begin{array}{l}\text { F: GAGGCAAGAGAAAATGATG } \\
\text { R: AGTCTGGGCTGTGTGTAAA }\end{array}$ & $205-217$ & $(\mathrm{GA})_{15}$ & 50.0 & 0.469 & 0.4667 & 0.6017 \\
\hline Lc 2-15 & $\begin{array}{l}\text { F: TACAGATTACCAGAAAACC } \\
\text { R: CAAATTCAAACTTACGATT }\end{array}$ & $290-311$ & $(\mathrm{CA})_{20}$ & 44.0 & 0.305 & 0.0667 & 0.0644 \\
\hline Lc 2-32 & $\begin{array}{l}\text { F: AACCGAGAAGTTGGAAAT } \\
\text { R: GTGATGCTTGTGATGAGG }\end{array}$ & $180-195$ & $(\mathrm{GA})_{31}$ & 44.0 & 0.559 & 0.1333 & 0.4911 * \\
\hline Lc 4-22 & $\begin{array}{l}\text { F: ACCATAATATCACGCACACA } \\
\text { R: AAGCACCAGAAATCTTCAAA }\end{array}$ & $133-141$ & $(\mathrm{TC})_{21}$ & 56.0 & 0.530 & 0.2000 & $0.5828 *$ \\
\hline Lc 4-31 & $\begin{array}{l}\text { F: TGTGAGTCTTTTTTTGTTGG } \\
\text { R: TCGTGCTTTGTTATTTCTGT }\end{array}$ & $200-204$ & $\begin{array}{l}(\mathrm{TC})_{7} \mathrm{C}- \\
(\mathrm{CT})\end{array}$ & 46.0 & 0.417 & 0.5667 & 0.4861 \\
\hline Lc $4-33$ & $\begin{array}{l}\text { F: TTATCACAATGGAAACGGG } \\
\text { R: TCAACAAAGCCTAGCAAAG }\end{array}$ & $141-148$ & $\begin{array}{l}(\mathrm{GT})_{6} \mathrm{GC}- \\
(\mathrm{GT})_{18}\end{array}$ & 46.0 & 0.375 & 0.3667 & 0.4061 \\
\hline Lc 4-45 & $\begin{array}{l}\text { F: GCACAAGAAAAAGCCACC } \\
\text { R: GGACTGAACCCACGATGA }\end{array}$ & $200-209$ & $(\mathrm{AG})_{19}^{18}$ & 44.0 & 0.339 & 0.5000 & 0.3750 \\
\hline Lc 4-50 & $\begin{array}{l}\text { F: CACACATAGACACCGACA } \\
\text { R: TACTGCTACCACAACACC }\end{array}$ & $171-182$ & $(\mathrm{AC})_{16}$ & 44.0 & 0.580 & 0.7333 & 0.6628 \\
\hline Lc 4-75 & $\begin{array}{l}\text { F: TACAAGAGTAGGGGAACAT } \\
\text { R: TGGGTGAATAAATAGAAAC }\end{array}$ & $160-170$ & $\begin{array}{l}(\mathrm{GA})_{5} \mathrm{~N}- \\
(\mathrm{GT})_{3}\end{array}$ & 58.0 & 0.361 & 0.4667 & 0.3578 \\
\hline Lc 4-90 & $\begin{array}{l}\text { F: TGTGTTCATGGCGATATAG } \\
\text { R: TTTAGGTTTGTACTTGGAT }\end{array}$ & $124-130$ & $(\mathrm{ATGCC})_{3}$ & 58.0 & 0.339 & 0.3333 & 0.4978 \\
\hline
\end{tabular}

$\mathrm{Ta}=$ annealing temperature; $H_{\mathrm{O}}=$ observed heterozygosity; $H_{\mathrm{E}}=$ expected heterozygosity; PIC $=$ polymorphism information content. *Significant departure $(\mathrm{P}<0.005)$ from expected Hardy-Weinberg equilibrium conditions after correction for multiple tests $(\mathrm{k}=10)$.

\section{ACKNOWLEDGMENTS}

Research supported by the National Natural Science Foundation of China (\#31272668), the Program for New Century Excellent Talents in Fujian Province University, and the Foundation for Innovative Research Team of Jimei University, China (\#2010A004).

\section{REFERENCES}

Cao YY, Li ZB, Zhang GL, Chen XJ, et al. (2012). Isolation and characterization of ten microsatellite markers of Fenneropenaeus penicillatus. Conserv. Genet. Resour. 4: 261-263. 
Chen JQ (1990). Solution effects of digestive enzyme from Lunella coronata granulata on the cell wall of seaweed. $J$. Xiamen Fish. Coll. 2: 21-26.

Chen LN, Li ZB, Chen XJ, Cao YY, et al. (2012a). Isolation and characterization of 15 microsatellite loci in Acrossocheilus labiatus Regan (Cyprinidae). Conserv. Genet. Resour. 4: 167-169.

Chen XJ, Li ZB, Chen LN, Cao YY, et al. (2012b). Isolation and characterization of new microsatellite markers in the pen shell Atrina pectinata (Pinnidae). Genet. Mol. Res. 11: 2884-2887.

Kalinowski ST, Taper ML and Marshall TC (2007). Revising how the computer program CERVUS accommodates genotyping error increases success in paternity assignment. Mol. Ecol. 16: 1099-1106.

Li Q (2006). Development of microsatellite DNA markers and their applications in genetic studies of marine mollusks. $J$. Fish. Sci. China 3: 503-509.

Van Oosterhout C, Hutchinson WF, Wills DPM and Shipley P(2004). MICRO-CHECKER: software for identifying and correcting genotyping errors in microsatellite data. Mol. Ecol. Notes. 4: 535-538.

Xu TJ, Quan XQ, Sun YN, Zhao KC, et al. (2010). A first set of polymorphic microsatellite loci from the marbled rockfish, Sebastiscus marmoratus. Biochem. Genet. 48: 680-683.

Yeh FC, Yang R, Boyle TJ, Ye Z, et al. (2000). PopGene32, Microsoft windows-based freeware for population genetic analysis. Version 1.32. Molecular Biology and Biotechnology Centre, University of Alberta, Edmonton.

Zane L, Bargelloni L and Patarnello T (2002). Strategies for microsatellite isolation: a review. Mol. Ecol. 11: 1-16. 